\title{
Lateral Moves and the Quest for Clients: Tort Liability of Departing Attorneys for Taking Firm Clients
}

The increasing frequency of lateral moves by attorneys and the competitive market for legal services have focused attention on the rules regulating competition for clients. Departing attorneys who take clients may be held liable to their former firms for intentional interference with economic relations. According to the Restatement (Second) of Torts, liability in such cases will turn on whether the interference by the departing attorney is "improper." The Restatement enumerates seven factors to be considered in deciding the issue of impropriety. That formulation is problematic, however, in that it offers little guidance as to how to weigh those factors.

This Comment argues for the development of a new test for use in departing-attorney cases. The proposed test evaluates the attorney's conduct and assesses liability where that conduct is independently unlawful or violative of ethical rules regarding lawyer communication with clients. This new test clarifies the application of the tort, thereby facilitating a freer fiow of commercial information in the legal market.

\section{INTRODUCTION}

Gone are the days when young lawyers signed up with law firms directly out of law school and expected to remain with the same firms throughout their careers. An mcreasing number of associates are making at least one lateral move durmg their careers for a variety of reasons-job dissatisfaction, geographic preference, or greater opportunities for making partner. ${ }^{1}$

Partners, too, have recently demonstrated an increasing willingness to cut ties with their firms. ${ }^{2}$ The reasons cited for this trend include a

1. See Hampton, Associate Tumover: Why They Leave and Why They Stay-Part III, 25 LAw OFF. ECON. \& MGMT. 16 (1984).

2. See, e.g., Adler \& Baer, The Final Shakeout, Am. Law., June 1986, at 1, col. 1; Pollock, Till A Better Deal Do Us Part, Am. Law., Oct. 1985, at 1, col. 1; Stewart, A Blue-Chip Law Firm Comes On Hard Times After a Coup d'Etat: Donovan Leisure Faces Risk Some Clients May Follow Top Partners in Leaving, Wall St. J., Nov. 18, 1983, at 1, col. 6; Kaplan, The Rush to Lateral Hires: Why Partners Switch Firms: Boredom, Power, Money, Nat'1 L.J., Oct. 31, 1983, at 1, col. 1; Low, Departing Lawyers Could be Liable for Taking Clients, L.A. Daily J., Aug. 22, 1983, at 1, col. 4; Courie, Lateral Partnerships: No Longer Rare Occurrence, Legal Times Wash., Apr. 6, 1981, at 32, col. 1; Fox, Law Firm Sues Ex-Partners For Taking Clients With Them, N.Y.L.J., Sept. 3, 1980, at 1, col. 2. 
diminished sense of obligation to the partnership, as well as a greater tendency on the part of law firms to search out legal talent. ${ }^{3}$ The latter tendency, in turn, derives froin a inore aggressive attitude on the part of law firms toward expanding existing, and developing new, practice areas. In general, law firms liave becoine much nore active in seeking out new business. $^{4}$

While firms offering lateral partnerships are quick to avow that a candidate must be "an excellent lawyer," such firms also are clearly attracted to a lateral partner by the clients the partner will bring with her to the firm. ${ }^{5}$ To a lesser extent, the same is true for a lateral associate. In some cases, even an associate nay have developed a strong relationship with a client to be able to entice that client to follow her to the new firm. Therefore, the attorney leaving her firm for a new firm is keenly interested in bringing her clients with her to the new firm. The attorney's old firm has an equally keen interest in retaining the client. Out of this situation arises the issue of the permissible limits of coinpetition for clients.

Several bodies of law dictate how attorneys nay behave when coinpeting for clients. Both the departing attorney and the attorneys at her former firm must conforin their conduct toward the client to the requirements of the profession's ethical rules. The relevant rules in this regard are those regulating lawyer commumications with potential clients, specifically the prohibitions of false or inisleading statements, and of the "solicitation" of clients. ${ }^{6}$ Such rules, while not defining "ethical" conduct, do provide a minimum "floor" for ethical behavior, below which a lawyer's beliavior must not fall.

Departing attorneys, whether partners or associates, are also bound by certain fiduciary duties to their foriner firms. In the case of associates, these duties stein from their status as ex-employees and derive from principles of the law of agency. One duty of ex-einployees is to account for profits arising out of einployment. ${ }^{7}$ For partners, these duties arise out of their status as ex-partners and are found in partnership law. One duty of ex-partners is the duty to wind up unfinished partnership business. ${ }^{8}$

In addition to these fiduciary duties, the departing attorney also acquires, as a new competitor with the firm, the duty to compete fairly for chients. In contrast to the fiduciary duties owed by the attorney as an ex-employee or as an ex-partner, the duty to coinpete fairly derives from the lawyer's status as a competitor of the firm. This duty to compete

3. Kaplan, supra note 2, at 1.

4. Courie, supra note 2, at 32 .

5. Id.

6. See infra text accompanying notes 87-93.

7. E.g., RESTATEMENT (SECOND) OF AGENCY $\$ 388$ (1958) (duty to account for profits arising out of employment); id. $\S 403$ (liability for things received in violation of duty of loyalty).

8. UNIFORM PARTNERSHIP ACT $\S 37$ (dealing with the winding-up of partnership affairs). 
fairly finds expression, inter alia, in the common law tort of intentional interference with economic relations. Thus, the departing attorney inay be held liable to her former firm for intentional interference with economic relations between the firm and a client. According to the Restatement (Second) of Torts, tort hability will turn on whether the interference by the attorney is "improper," which in turn is determined by a consideration of several enumerated factors. ${ }^{9}$ The weight eacl factor should be assigned in the balancing process, as well as what constitutes a sufficient showing to establislı liability, however, are issues not addressed by the Restatement.

The current means of determining hability for intentional interference raises several probleins. One problein hes in the vagueness of the legal standards for determining hability. Lack of a concrete test of hability poses probleins for tlie departing attorney who wishes to communicate with chients regarding her departure and willingness to represent thein in the future. This uncertainty about liability inay "chill" the beliavior of the departing attorney, especially where, as here, the rules defining minimum acceptable behavior-the ethical rules-are in a state of flux. Moreover, the dimensions of a "chilling" effect are greater in a market such as the current legal inarket where attorneys are changing firms in ever-increasing numbers and firms are coinpeting inore aggressively for clients. In order to facilitate the transition of the legal inarket from highly uncoinpetitive to the coinpetitive model now being pursued, the rules regulating "fair competition," such as the duty not to interfere improperly with economic relations, need to be more clearly defined.

Another problein with the existing ineans of determining liability for intentional interference is its unprimcipled nature. Because tliere exists little guidance as to how to balance the array of factors enuinerated in the Restatement, courts have wide discretion in determining which factors they find dispositive of the issue of liability. The open-ended balancing test of the Restatement ${ }^{10}$ thus permits the courts to engage in inquiries that they are either ill-equipped to decide, or tliat raise concerns best liandled by other bodies of law, namely partnership and agency law. Because partnership and agency issues often arise in a departing attorney situation, a vague liability standard risks confusing tort issues with fiduciary issues. This confusion is problematic because the respective duties address different values and should be kept distinct.

This Coinment focuses on the liability of departing attorneys for intentional interference with the former firm's relations with its clients. Thus, it examines the duty owed by the departing attorney as a coinpeti-

9. RESTATEMENT (SECOND) OF TORTS $\$ \$ 766,767$ (1979). See infra notes $23-50$ and accompanying text.

10. See infra notes $23-52$ and accompanying text. 
tor with the firm, as distinguished from duties as an ex-partner or exemployee. It argues that, because consistent factual patterns can be discerned in the departing-attorney context, a more focused test can be used to determine the liability of attorneys for intentional interference with economic relations.

The test proposed by this Comment offers two advantages over the current regime. First, it reduces the uncertainty surrounding the standards for hability by focusing on the factors that should determine liability. Second, by narrowing the focus of the imquiry, the proposed test avoids the problems associated with considering those factors which may be relevant to partnership or agency duties, but which are not relevant to the duty imposed by the tort of imtentional interference witl economic relations.

Part I of this Comment reviews the relevant background law. Section A examines the prevailing law on intentional interference with economic relations, focusing especially on the factors considered in the Restatement balancing test and notes low the interfering party's conduct is relevant to hability. Section B discusses existing standards for judging an attorney's conduct toward potential clients. This Section examines the relevant ethical rules and the constitutional limits placed upon such rules. Part II reviews the cases which have addressed the issue of intentional interference with economic relations in the departing-attorney context and discusses the patterns and problems raised by these cases.

Part III develops a new test by examining the Restatement factors for assessing liability in the departing-attorney context. The proposed test focuses on the underlying conduct of the departing attorney and imposes liability when the attorney's behavior is either independently wrongful or violative of ethical rules of professional conduct. No presumption of liability would arise as the result of a breach of fiduciary duty. This Part slows how the proposed test improves the law, addresses possible objections to the proposed test, and explains why it is appropriate to develop a test specific to the legal profession. This Part also applies the proposed test to the cases discussed in Part II, as well as to the situation of interference with prospective relations. This Part concludes that the proposed test better carries out the pohicy underlying the interference tort than does the Restatement balancing test, and that the proposed test benefits the legal profession and its clients by making clear the bases and limits of liability. 
I

\section{BACKGROUND LAW}

\section{A. Liability for Intentional Interference with Contractual Relations or Prospective Economic Relations}

The "interference" torts-intentional interference with contractual relations and intentional interference with prospective econoinic relations-innose tort liability upon third persons for interfering witl private economic relationships between two other parties. ${ }^{11}$ The interference tort doctrine presents an interesting interplay between tort law and contract law in that tort law-collective allocation of loss-is used to protect, rather than override, the terms of a contract-private allocation of loss (or gain). ${ }^{12}$

The historical underpinnings of the interference tort grew out of the Black Plague in England in the 14tll century, which liad created a severe labor shortage. In recognition of the resulting strain on employers, the Ordinance of Labourers ${ }^{13}$ was enacted, providing that no person, unless independently wealtliy or engaged in a craft, could leave his work. To strengthen this prohibition, it was furtler provided that no other employer could hire such a person, thus introducing the notion of thirdparty liability for inducing the breach of a private econoinic relationship.

The modern origin of the interference tort dates froin the 1853 English case, Lumley v. Gye. ${ }^{14}$ The case marked the first extension of the tort to employees who were not "servants." In that case, the defendant, the manager of a theater, enticed an opera singer under contract to a competing theater to sing for his production instead. ${ }^{15}$ In an action brought by the spurned producer against the enticer, the Queen's Bencli announced a general rule of tort hability for "wrongfully and maliciously, or, which is the saine thing, with notice," interrupting a personal service contract, regardless of the means used. ${ }^{16}$ Courts later extended liability to a vari-

11. The two torts differ in that one-intentional interference with contractual relationsrequires the existence of a contract, while the other-intentional interference with prospective economic relations-simply requires a prospective economic relationship. RESTATEMENT (SECOND) of TORTS $\S \S 766,766$ B (1979). See also W. KeEton, D. DobBS, R. KEeton \& D. OWEN, PROSSER AND KEeTON ON THE LAW OF TORTS, $\$ \S 129-130$ (5th. ed. 1984) [hereinafter Prosser AND KEETON]. The type of relationship interfered with-existing contractual relations or prospective economic relations-will affect the degree to which the interfering party can interfere with the relationship without being subject to tort liability. See infra note 40 and accompanying text.

12. See Perlman, Interference with Contract and other Economic Expectancies: A Clash of Tort and Contract Doctrine, 49 U. CHI. L. REv. 61, 62 (1982).

13. 23 Edw. 3 (1349).

14. 2 El. \& Bl. 216, 118 Eng. Rep. 749 (Q.B. 1853).

15. See Lumley v. Wagner, 91 Rev. Rep. 193, 193-95 (Ch. 1852).

16. Lumley v. Gye, 2 El. \& Bl. at 224, 118 Eng. Rep. at 752 (opinion of Crompton, J.). 
ety of contracts ${ }^{17}$ and to economic relationships not yet formalized into contract. $^{18}$ Eventually, the requisite proof of malice became so flexible that it came to be regarded as superfluous and ceased to be a necessary element of the tort. ${ }^{19}$ Due in part to the historically expanding nature of the tort and to the inability of courts and commentators to develop a coherent doctrine, ${ }^{20}$ the interference tort has been criticized both for its scope and for its uncertainty in apphication. ${ }^{21}$ The absence of a coherent doctrine, and the resulting problems of scope and uncertain application, can be attributed to the wide variation found in the context, terms, and subject matter of different economic relationships. ${ }^{22}$

The confusion surrounding the contours and application of the tort is well illustrated by the "codification" of the tort in sections $766^{23}$ and $766 \mathrm{~B}^{24}$ of the Restatement. The elements of the tort as codified are intent to imterfere, ${ }^{25}$ actual imterference, ${ }^{26}$ and "improper" interfer-

17. See, e.g., Temperton v. Russell, 1 Q.B. 715 (1893) (extending application of tort to nonservice contracts and recognizing liability for interference with prospective economic relations). For an alternative view of the history of the tort, see Note, Tortious Interference with Contractual Relations in the Nineteenth Century: The Transformation of Property, Contract, and Tort, 93 HARV. L. REV. 1510 (1980).

18. Walker v. Cronin, 107 Mass. 555 (1871).

19. See Lamb v. S. Cheney \& Son, 227 N.Y. 418,125 N.E. 817 (1920) (defining malice as signifying neither ill will nor intent to injure, but rather as indicating the intentional interference with a known legal or contractual right).

20. See Prosser ANd KeEton, supra note 11, at 979.

21. See Dobbs, Tortious Interference with Contractual Relationships, 34 ARK. L. REV. 335, 356-58 (1980) (criticizing the tort on grounds of "justice"); Perlman, supra note 12, at 61-62 (criticizing the scope of the tort on efficiency grounds).

22. See Perlman, supra note 12, at 61-62. The significance of the wide variation in factual circumstances is that the acceptabihity of a particular interference depends on, among other things, the nature of the economic relationship, the relationships of the parties, and the means used to interfere. See infra text accompanying notes 26-50.

23. RESTATEMENT (SECOND) OF TORTS \& 766 (1979) (Intentional Interference with Performance of Contract by Third Person):

One who intentionally and improperly interferes with the performance of a contract... between another and a third person by inducing or otherwise causing the third person not to perform the contract, is subject to hability to the other for the pecuniary loss resulting to the other from the failure of the third person to perform the contract.

24. Id. § 766B (Intentional Interference with Prospective Contractual Relations):

One who intentionally and improperly interferes with another's prospective contractual relation ... is subject to liability to the other for the pecuniary harm resulting from loss of the benefits of the relation, whether the interference consists of (a) inducing or otherwise causing a third person not to enter into or continue the prospective relation or (b) preventing the otler from acquiring or continuing the prospective relation.

25. Id. $\S \S 766 \& 766 \mathrm{~B}$. Negligent interferences nsually are not actionable; see id. $\S 766 \mathrm{C}$. But see J'Aire Corp. v. Gregory, 24 Cal. 3d 799, 598 P.2d 60, 157 Cal. Rptr. 407 (1979), for a case upholding a clain for negligent interference with prospective advantage. The California Supreme Court based liability on the foreseeability of the plaintiff's injury and the absence of due care on the part of the defendant. It has been suggested, lowever, that the case is best understood as an extended form of third-party beneficiary contractual liability. See Note, Tortious Interference with Contract: A Reassertion of Society's Interest in Commercial Stability and Contractual Integrity, 81 Colum. L. Rev. 1491, 1507-08 (1981).

26. REstatemENT (SECOND) OF TORTS, $\S \S 766,766 \mathrm{~B}$ (1979). 
ence. ${ }^{27}$ The requirement of impropriety is both the most contentious and the least certain element of the tort. ${ }^{28}$ The Restatement provides a list of seven factors to be balanced in determining whether a particular interference is "improper," and therefore actionable. ${ }^{29}$

The first listed factor, "the nature of the actor's conduct,"30 relates to the means used to cause the harm. ${ }^{31}$ The Restatement notes that some means may be independently tortious, while others may not. ${ }^{32}$ The ineans must also be considered in conjunction with the circuinstances of each case, because "the same ineans may be permissible under some circumstances while wrongful im others." 33 As a further consideration, the Restatement notes the potential importance of business ethics and customs for a particular area of busmess activity in evaluating the nature of the actor's conduct. ${ }^{34}$

The second factor, "the actor's motive,"35 primarily concerns the issue of malice, that is, "whether the actor was motivated, in whole or in part, by a desire to interfere with the other's contractual relations,"36 as opposed to a desire to contract with the third party, with the inevitable result of interference. ${ }^{37}$ While malice is not a necessary element of the tort, its presence apparently weighs toward liability.

The third factor, "the interests of the other with which the actor's conduct interferes," 38 examines the nature of the economic relationship

27. Id. $\$ \$ 766$ comment a, $766 \mathrm{~B}$ comment a (stating that interference must be "iinproper" in order for the actor to be held hable).

28. See Prosser AND KEETON, supra note 11, $\$ 129$, at 984 . A related problem is the burden of proof, that is, whether a plaintiff has made out a prima facie case with proof of interference and intent, with the burden on the defendant to show justification, or whether a plaintiff must plead and prove that the interference was improper. See id. at 983-84; Perlman, supra note 12, at 65-69. The Restatement leaves this question open, recognizing the split among the states. See infra note 29.

29. RESTATEMENT (SECOND) OF TORTS, $\$ 767$ (1979). With respect to the burden of proof, the section notes that some of the listed factors are "soinetimes treated as going to the culpability of the actor's conduct in the beginning, rather tlian to the determination of wliether his conduct was justifiable as an affirmative defense." Id. $\$ 767$ comment b. The drafters, however, do not specify which factors miglit be considered as part of an affirmative defense. They note that "there is little consensus on who has the burden of raising the issue of whether the interference was improper or not and subsequently of proving that issue." Id. comment $\mathrm{k}$.

30. Id. $\S 767(\mathrm{a})$.

31. See id. $\$ 767$ comment c.

32. Id.

33. Id.

34. Id.:

Violation of recognized ethical codes for a particular area of business activity or of established customs or practices regarding disapproved actions or methods may also be significant in evaluating the nature of the actor's conduct as a factor in determining whether his interference with the plaintiff's contractual relations was improper or not.

35. Id. $\S 767(\mathrm{~b})$.

36. Id. $\$ 767$ comment d.

37. Id. (noting that where the sole motivation is a desire to interfere, the interference is almost always improper).

38. Id. $\S 767(\mathrm{c})$. 
interfered with. ${ }^{39}$ Some economic interests receive greater protection than others; for example, existing contractual interests are more protected than prospective economic relations, and contracts terminable at will receive less protection than other contracts. ${ }^{40}$

The correlative factor to this consideration is "the interests sought to be advanced by the actor," party. This fourth factor is considered inost closely in conjunction with "the interests of the other," since, for example, where the interest of both is economic, and still only prospective (not yet formalized into contract), the interference by one party will usually be deemed permissible competition. ${ }^{42}$ In such a situation, the interest in "free competition" requires that the economic interest of one actor not be protected over that of another actor. The obvious relevance is that both parties' interests must be considered im order to determine whether one is deserving of protection from the other. ${ }^{43}$

The fifth factor, "the social interests in protecting the freedom of action of the actor and the contractual interests of the other," ${ }^{44}$ recognizes that consideration of the economic interests of the respective parties will often be inconclusive, in which case the social interests should be examined. ${ }^{45}$ The most significant social interests involved are those of encouraging free coinpetition and discouraging persuasion by unsuitable (for example, tortious) means. ${ }^{46}$

The Restatement cites as the sixth factor a consideration of "the proximity or remoteness of the actor's conduct to the interference."47 For example, the Restatement suggests examining whether the interference is a direct consequence of the actor's conduct or whether the interference is a more remote and indirect consequence of the actor's conduct. ${ }^{48}$

39. Id. $\$ 767$ comment e. For example, the court should consider whether the party's economic expectancy has been formalized into contract or is merely prospective. The strength of the party's expectancy is significant in that the stronger the expectancy, the greater the claim to security and the less social utility in the interfering party's conduct. Other relevant considerations in evaluating the other's interest include whether the contract violates public policy or is otherwise not worthy of protection.

40. Id.

41. Id. $\S 767$ (d).

42. Id. $\$ 767$ comment $f$. For the discussion of competition as justifieation, see infra text accompanying notes 55-58.

43. Also of possible relevance is whether the actor is seeking to promote a public interest as well as his own, thus outweighing the interest of the other.

44. RestateMENT (SECOND) OF TORTS § 767(e) (1979).

45. Id. $\S 767$ comment $\mathrm{g}$.

46. $I d$.

47. Id. $\S 767(\mathrm{f})$.

48. Id. $\S 767$ comment h. 
Finally, "the relations between the parties,"49 (between any two of the parties) inay be significant. For example, the interfering party and the party complaining of the interference may be competitors, or the interfering party and the third party inay have some special relationship, as where the interfering party is a business advisor or bears some fiduciary obligation toward the third party. ${ }^{50}$

While the Restatement provides a hist of relevant factors to be considered in determining whether an imterference is iniproper, the drafters conclude that, owing to the crucial nature of the particular circumstances of each case, no further generalizations about hability can be made. ${ }^{51}$ How to balance each factor, and what weight to assign to each, remain tied to the circumstances of each case..$^{52}$ In recognition of the vagneness of such an approach, however, the drafters note that some factual patterns have developed such that "crystallized privileges or rules defining conduct that is not improper" can be discerned. ${ }^{53}$ The results of the balancmg process in several such situations are deinonstrated in sections 768 through $777 .^{54}$

One such "crystallized pattern" concerns society's interest in free competition. As a necessary imcident to a free enterprise econoinic system, parties may be protected from hability for imterference due to a "coinpetition privilege." ${ }^{\text {Th }}$ The Restatement recognizes this privilege where the econoinic relationship interfered with is merely prospective or where it is an existing contract terminable at will. ${ }^{56}$ In such cases, the

49. Id. $\S 767(\mathrm{~g})$.

50. Id. $\S 767$ comment $\mathrm{i}$.

51. Id. \$ 767 comment b.

52. Id. The drafters here suggest a similarity between the standard for negligence and the standard for improper interference: each factual situation is unique. The enumeration of relevant factors by tlie drafters, however, demonstrates an attempt to derive a more specific standard than the negligence "reasonable person" standard. As will be slown later, in the departing-attorney context, the factors can be further refined, thus providing an even more specific standard.

53. Id.

54. Id. $\S 768$ (Competition as Proper or Improper Interference); id. $\S 769$ (Actor Having Financial Interest im Bnsiness of Person Induced); id. $\S 770$ (Actor Responsible for Welfare of Anotlior); id. $\S 771$ (Inducement to Influence Another's Business Policy); id. § 772 (Advice as Proper or Improper Interference); id. $\S 773$ (Asserting Bona Fide Claim); id. §774 (Agrecment Illegal or Contrary to Public Policy).

55. Id. $\S 768$. "One's privilege to engage in business and to compete witl others implies a privilege to induce tliird persons to do their business with him ratler than with his competitors." Id. comment $b$.

56. Id. $\S 768:$

One who intentionally causes a third person not to enter into a prospective contractual relation witls anotler who is his competitor or not to continue an existing contract terminable at will does not interfere improperly with the other's relation if (a) the relation concerns a matter imvolved in the competition between the actor and the other and (b) the actor does not employ wrongful means and (c) lis action does not create or continue an unlawful restraint of trade and (d) his purpose is at least in part to advance his interest in competing with the other. The fact that one is a competitor of anotler for the bnsiness of a 
interfering party and the party interfered with stand in substantially the saine position with respect to the third party since both parties enjoy only a hope of future relations with the third party. The societal interest in free coinpetition thus favors allowing both parties freedoin of action in seeking economic relations with the third party, ${ }^{57}$ with neither party favored over the other. ${ }^{58}$

Another "crystallized pattern" relevant to the departing-attorney context concerns "Advice as Proper or Inproper Interference." 59 Section 772 of the Restatement deals with two situations: (1) the giving of truthful information; and (2) the giving of honest advice. ${ }^{60}$ The latter situation protects the interfering party whenever three requireinents are inet: (1) the advice is requested; (2) the advice given is within the scope of the request; and (3) the advice is honest. ${ }^{61}$ This protection is essential to protect certain professionals, such as lawyers, doctors, and investinent advisors in the perfornance of their jobs. Immunizing such persons from hability for giving truthful information and honest advice allows thein to fulfill their fiduciary obligations to their clients. ${ }^{62}$

The Restatement thus lays out several factors which inay be relevant in a given case to determine whether a party's interference was "imiproper" and thus actionable under an interference tort theory. The "crystallized patterns" identified by the Restatement also suggest ways of analyzing an interference where certain factors are present. Even with these "crystallized patterns," however, the Restatement approach to analyzing interferences reinains vague in two respects. First, it doesn't assign a hierarchy of values in the balancing process, that is, the relative weight of each relevant factor is not specified. Second, the Restatement does not indicate what constitutes a sufficient showing to establish liability; that is, it does not reveal what is necessary to "tip the balance."

As a means to developing a more precise hability standard, the following Section isolates one of the Restatement factors, "the nature of the

third person does not prevent his causing a breach of an existing contract with the other from being an inproper interference if the contract is not terminable at will.

57. See Prosser AND KeEton, supra note 11, §§ 129-130, at 987-88, 1012-13.

58. The qualifying phrases of section 768 of the Restatement recognize that other factors, such as the means of inducenent and the inotive of the actor, nay justify protecting the other froin the interference. For example, an interference otherwise proper because of a privilege to compete, may be improper where the actor uses tortious ineans.

59. RESTATEMENT (SECOND) OF TORTS $\S 772$ (1979):

One who intentionally causes a third person not to perform a contract or not to enter into a prospective contractual relation with another does not interfere inproperly with the other's contractual relation, by giving the third person (a) truthful information, or (b) honest advice within the scope of a request for the advice.

60. Id.

61. Id. coininent c.

62. Id. 
actor's conduct," 63 in the departing-attorney context in an effort to elucidate the meaning of "improper" for that situation. In doing so, the Section looks at ethical restraints upon the conduct of attorneys and identifies specific limitations thereby imposed upon the competition for prospective clients.

\section{B. Ethical Restraints Upon the Conduct of Attorneys}

In addition to the tort law's proscription against improper interferences with economic relations, ethical rules independently constrain attorneys in their dealings with chents and prospective clients. Ethical codes and the accompanying bodies of case law inform the mquiry of whether an attorney has "improperly" interfered with an economic relationship. ${ }^{64}$ Thus, a review of the constraints imposed by the ethical rules and of the cases imterpreting those rules will help define what conduct is "improper" in the departing-attorney context.

Traditionally, lawyers were absolutely prohibited from seeking out clients. ${ }^{65}$ The evolution of the doctrine of commercial speech ${ }^{66}$ however, has altered the extent to which the profession may restrict lawyers in their search for business. The recognition of a limited annount of constitutional protection for commercial speech signifies that not all active searches for legal business may be prohibited. In several cases, the United States Supreme Court has explicitly dealt with the limits which the states nray place on lawyers im publicizing their practice. Examining these cases will identify these limits, as well as the policy reasons underlying the ethical rules dealing with commurncations with potential chents. The factual context of each case, while not imvolving the departingattorney situation, should also help to illustrate the potential dangers that the ethical rules seek to address.

In Bates v. State Bar of Arizona, ${ }^{67}$ the Court relied on the first amendnient to hold that states may not prohibit the truthful advertising of routime legal services. ${ }^{68}$ In that case, two members of the Arizona State Bar were disciplined for advertising their legal chinic in a newspaper. The advertisements stated that the attorneys were offering "legal services at very reasonable prices," and histed their fees for certain services. ${ }^{69}$

63. Id. § 767(a).

64. For example, violation of an ethical code is relevant to the examination of "the nature of the actor's conduct." The Restatement also explicitly notes the possible importance of business ethics and customs in evaluating such conduct. See supra text accompanying notes 30-34.

65. See Model Rules of Professional Conduct Rule 7.2 comment (1983).

66. See, e.g., Virginia Pharmacy Bd. v. Virginia Consumer Council, 425 U.S. 748 (1976).

67. 433 U.S. 350 (1977).

68. Id. at 384 .

69. Id. at 354 . 
The Court ruled that the advertising of legal services is not inherently misleading, ${ }^{70}$ and that the other justifications advanced by the state for the prohibition were not sufficient to justify burdening the speech. ${ }^{71}$ The Court also cited "the consumer's concern for the free flow of commercial speech."72 The Court did say, however, that advertising by lawyers could be regulated, citing as examples advertising that is false, deceptive, or misleading. Due to the public's lack of sophistication concerning legal services, misstateinents that were acceptable in other areas of advertismg might be "quite inappropriate in legal advertising."73 The Court also specifically noted that the case did not raise the issue of whether states could prohibit m-person solicitation of clients by attorneys. ${ }^{74}$

The Court subsequently addressed the issue of in-person solicitation by attorneys in Ohralik v. Ohio State Bar Association. ${ }^{75}$ The case

70. Id. at 372. Commercial speech that is false, deceptive, or misleading is subject to restraint. Id. at 383 (citing Virginia Pharmacy Bd., 425 U.S. at 771-72 \& n.24).

71. Id. at 368-72, 375-79. Among the justifications rejected by the Court were adverse effects on professionalism, adverse effects on administration of justice, undesirable economic effects, adverse effects on the quality of service, and difficulties of enforcement.

72. Id. at 364 .

73. Id. at 383.

74. Id. at 384. The Court has since decided two more cases challenging restrictions on lawyer advertising. In In re R.M.J., 455 U.S. 191 (1982), a lawyer was disciplined for publishing advertisements listing areas of practice in language other than that specified in the state's disciplinary rule, and listing conrts in which the lawyer was permitted to practice although this imformation was not permitted by the rule. Id. at 196-98. The lawyer was also disciplined for mailing announcement cards to persons other than those permitted by the rule (otleer lavyers, chents, former clients, personal friends, and relatives). Id. The Court held that none of the restrictions upon the lawyer's first amendment rights could be sustained, noting that none of the information im the advertisements or announcements had been shown to be false or misleading, and that the state had failed to advance any other substantial interest justifying the restrictions. Id. at 205-07.

In Zauderer v. Office of Disciplinary Counsel, 471 U.S. 626 (1985), an attorney was disciplined for two allegedly deceptive advertisements. One of the advertisements offered to represent defendants in drunk driving cases and to refund full legal fees if they were convicted of drunk driving, and the other advertisement offered to represent women who liad suffered injuries from the Dalkon Shield. Id. at 629-35. The latter advertisement represented that "[i]f there is no recovery, no legal fees are owed by our chents," and featured an illustration of the Dalkon Shield. Id. at 63031. The Ohio Supreme Court adopted the disciplinary board's findings that tlic drunk driving advertiseinent's failure to mention the common practice of plea bargaining might be deceptive (and thus prohibited), id. at 635-36, that the Dalkon Shield advertisement violated a rule prohibiting the use of illustrations in lawyer advertisements, id. at 632 n.4, 636, and that the Dalkon Shield advertisement's failure to disclose the client's potential liability for costs even if her suit was unsuccessful violated the rule prohibiting "false, fraudulent, inisleading, deceptive" public commumications. Id. at $631 \mathrm{n.3}, 635-36$.

The Supreme Court held the disciplimary action sustainable to the extent that it was based on the drunk driving advertisement and the omission of information in the Dalkon Shield advertisement, noting the state's interest in preventing deceptive advertising. Id. at 650-55. The Court held, however, that the state lad failed to establislı a substantial interest sufficient to justify its prohibition against illustrations in lawyer advertisements. Id. at 647-49.

75. 436 U.S. 447 (1978). 
involved classic "ambulance-chasing": a lawyer, upon hearing about an automobile accident, visited one of the young women involved in the accident at her hospital room. After advising the woinan of the possibility of a recovery and of his availability to represent her, the lawyer induced the woinan to sign a contingency fee contract to be represented by the lawyer. ${ }^{76}$

The woman later discharged the lawyer, who then sued her for breach of contract and received one-third of her settlement. The woman filed a complaint against the lawyer with a bar grievance committee, which referred the complaint to the disciplinary board of the Ohio Supreme Court. The board found the lawyer to be in violation of the disciplinary rules prohibiting self-recommendation for employment and employment resulting from unsolicited legal advice. ${ }^{77}$ The lawyer appealed, arguing that the application of the disciplinary rules to him violated the first and fourteenth amendments. ${ }^{78}$

The Supreme Court held that a state may discipline a lawyer for soliciting chients "in person, for pecumary gain, under circumstances likely to pose dangers that the state has a right to prevent."79 The Court noted the state's interests im "Inamtaining standards among members of the licensed professions," tion that involve fraud, undue influence, intimidation, overreaching and other forms of 'vexatious conduct." "81 The Court concluded that since these potential dangers were inherent with in-person solicitation of chents by lawyers, the prophylactic regulations were justified. ${ }^{82}$

From the foregoing cases, several principles emerge regarding the extent to which states may restrict lawyers in their coinmumications with the public. First, the Court has recognized the legitimate interest of clients and potential chents in receiving adequate information to choose

76. Id. at 450 . The lawyer also succeeded im inducing the woman's passenger to be represented by him. Id. at 451 .

77. Id. at 451-53. The Ohio codes were essentially identical to DR 2-103(A) and DR 2104(A), respectively, of the Model CoDE OF Professional Responsibility (1980). Disciplinary rule 2-103(A) provides in pertinent part: "A lawyer shall not . . recommend employment as a private practitioner, of himself, his partner, or associate to a layperson who has not sought his advice regarding employment of a lawyer." Rule 2-104(A) provides in pertinent part: "A lawyer who has given in-person unsolicited advice to a layperson that he should obtain counsel or take legal action shall not accept employment resulting from that advice...."

78. Ohralik, 436 U.S. at 453-54.

79. Id. at 449 .

80. Id. at 460 .

81. Id. at 462 .

82. Id. at 468 . The companion case to Ohralik, In re Primus, 436 U.S. 412 (1978), involved an offer of frec legal services by a civil rights attorney. Because the inotives of the attorney with respect to the solicitations involved "a form of political expression," the solicitations constituted expressive and associational conduct and hence were more protected than the pure commercial speech in Ohralik. Id. at 431-34. 
how to be represented. ${ }^{83}$ Second, states may absolutely prohibit information that is false, misleading or deceptive. ${ }^{84}$ Third, states may regulate those communications which present a significant "potential for abuse," including the dangers of undue influence, intimidation, and overreaching. ${ }^{85}$ Finally, the Court has held that direct in-person solicitation (even if not false, misleading, or deceptive) presents these potential dangers and can be regulated. ${ }^{86}$ These principles are relevant in that they recognize the interest in providing clients with a meaningful choice as to representation, while defining the basic contours of how lawyers may be regulated in their quest for chents.

While the Court has established the basic parameters within which attorneys must operate, the more precise contours of ethical duties imposed on attorneys in their competition for business can be found in state ethical rules. By carefully examining the minimum conduct deinanded of attorneys by these rules, the intentional interference tort's requirement of "impropriety" can be better understood.

The Model Rules of Professional Conduct, ${ }^{87}$ promulgated by the American Bar Association in 1983, reflect a consideration of the constitutional limitations imposed by the Court in its series of lawyer publicity cases. Rule 7.1 generally prohibits false or misleading "communication" about the lawyer or the lawyer's services. ${ }^{88} \mathrm{~A}$ communication is "false or misleading" if it: "(a) contains a material misrepresentation of fact or law ... (b) is likely to create an unjustified expectation about results the lawyer can achieve ... or (c) compares the lawyer's services with other lawyer's services, unless the comparison can be factually substantiated."89 This rule would apply for any type of coinınunication by an attorney, whether deeined "advertising" or "solicitation.""90

Rule 7.3, "Direct Contact With Prospective Clients," prohibits the "solicitation" of professional employment from prospective clients "when a significant motive for the lawyer's domg so is the lawyer's pecuniary gain." "S1 "Solicitation" includes all coinniunications directed at "specific recipients," but does not include conımunications "distributed

83. Bates v. State Bar of Arizona, 433 U.S. 350, 364 (1977).

84. Id. at 383.

85. Ohralik, 436 U.S. at 462.

86. Id. at 468.

87. Model Rules of Professional Conduct (1983).

88. Id. Rule 7.1. The precursor to Rule 7.1 in the Model Code of Professional Responsibility, is DR 2-101(A), which is basically identical in its prohibitions.

89. Model Rules of Professional Conduct Rule 7.1 (1983).

90. Id. Rule 7.1 comment.

91. Id. Rule 7.3. The qualification of "pecumiary gain" apparently recognizes that solicitations may in some cases be a form of political expression, as in $I n$ re Primus, 436 U.S. 412 (1978), and thus entitled to greater protection. See supra note 82 . See also supra note 77 and accompanying text (discussion of Model Code of PROFessional ResponsibiLity DR 2-103 and DR 2-104). 
generally to persons not known to need legal services of the kind provided by the lawyer in a particular matter." 92 Significantly, the prohibition against "sohicitation" does not extend to persons with whom the lawyer has had a "prior professional relationship."93

The drafters note that direct solicitation carries with it an inherent "potential for abuse" due to the respective positions of lawyers and laypersons. This "abuse" may take the form of undue influence, imtimidation or overreaching. ${ }^{94}$ Advertising is considered more appropriate because it fulfills the function of sohcitation while subjecting the communications to public scrutiny. This scrutiny minimizes the possibility of false or misleading communications. ${ }^{95}$

The line between permissible "advertising" and prohibited "sohcitation" is not always clear. The Model Rules theinselves implicitly recognize a potential overlap between "advertising" and "solicitation." Rule 7.2 permits, subject to Rule 7.1, any advertising of services "not involving solicitation as defined in Rule 7.3."96

A particular communication inay share some characteristics of "advertising," and soine of "solicitation." In such cases, the problein is how to classify properly the communication in order to determine whether it violates the ethical rules. For example, several state courts have differed on whether form letters directed at specific types of businesses are (prohibited) solicitations or (permitted) advertiseinents. In Allison v. Louisiana State Bar Association, ${ }^{97}$ the Supreme Court of Louisiana held that the sending of letters by attorneys to employers describing prepaid legal plans for einployees was "solicitation" and prohibited. ${ }^{98}$ In Kentucky Bar Association v. Stuart, ${ }^{99}$ the Kentucky Supreine Court held that the sending of letters to real estate agencies stating prices for transactions and the qualifications of the attorneys, was "advertising" and

92. Model Rules of Professional Conduct Rule 7.3 (1983).

93. Id.

94. Id. Rule 7.3 comment. The Supreme Court has identified "potential for harm" in this context as a substantial state interest justifying regulation of lawyer publicity. See Ohralik v. Ohio State Bar Ass'n, 436 U.S. 447, 464 (1978).

95. Model Rules of Professional Conduct Rule 7.3 comment (1983).

96. Id. Rule 7.2. In contrast, the Model Code provision, promulgated in 1979 and adopted in various forms by many states, specified in detail the information that could be publicized. MODEL CODE OF PROFEsSional ResPonsibility DR 2-101(B) (1980). See discussion of Zauderer v. Office of Disciplinary Counsel, 471 U.S. 626 (1985), supra note 74. The drafters acknowledged the rule's departure from tradition: "[ $t$ ] to prevail over considerations of tradition." Model Rules of Professional Conduct Rule $\mathbf{7 . 2}$ comment (1983). Note how this statement echoes the concerns raised by the Court in Bates v. State Bar of Arizona, 433 U.S. 350 (1977). See supra text aceompanying notes 67-74.

97. 362 So. $2 d 489$ (La. 1978).

98. Id. at 496.

99. 568 S.W.2d 933 (Ky. 1978). 
permitted. ${ }^{100}$ Finally, in Koffler v. Joint Bar Association, ${ }^{101}$ the New York Court of Appeals, on facts similar to those in Stuart, reversed the lower court's decision and held that such letters were not proscribed as "solicitation."102

The Comment to the Model Rules ${ }^{103}$ attempts to resolve this difficulty in classifying such lawyer communications as "advertising" permitted under Rule 7.2, ${ }^{104}$ or as "solicitation" prohibited by Rule 7.3. ${ }^{105}$ The drafters note that "[g]eneral mailings not speaking to a specific matter" would not fall within the definition of Rule 7.3. ${ }^{106}$ The drafters reason that where a mailing does not address persons mvolved in a specific legal matter or incident, the recipients are unlikely to be particularly vulnerable to abuse. Hence, the dangers of solicitation-intinidation, undue influence, and overreaching - are not present in such a situation. ${ }^{107}$ However, in a situation where a lawyer addresses a person's known pending matter, the potential for abuse is present, and such communications are prohibited. ${ }^{108}$

The Model Rules provide the departing attorney with guidelines on low to tailor her communications with former clients. First, the attorney must not make any false or misleading representations to a former client, particularly witli respect to any factor bearing on the client's choice about representation. ${ }^{109}$ An example of such a misrepresentation would be telling the client that the firm, without the attorney, would be disqualified from representing the client. Another prohibited category of communication would be one "likely to create an unjustified expectation" of success in the client. ${ }^{110}$ This category would include statements about the results obtained on behalf of other clients, sucli as the size of damage awards or the number of favorable verdicts. ${ }^{11}$ Similarly, the attorney could not predict the outcome slie could obtain on behalf of the client. Finally, witl respect to false and misleading statements, the attorney could not draw comparisons between the attorney and the firm that could not be factually substantiated. ${ }^{112}$ Thus, for example, the attorney

100. Id. at 934 .

101. 51 N.Y.2d 140, 412 N.E.2d 927, 432 N.Y.S.2d 872 (1980), cert. denied, 450 U.S. 1026 (1981).

102. Id. at 143,412 N.E.2d at 929,432 N.Y.S.2d at 873 .

103. Model Rules of Professional Conduct Rule 7.3 comment (1983).

104. Id. Rule 7.2 .

105. Id. Rule 7.3.

106. Id. Rule 7.3 comment.

107. Id.

108. Id.

109. Id. Rule 7.1.

110. Id.

111. Id. Rule 7.1 comment.

112. Id. Rule 7.1. 
could point to differences in billing rates (where ascertainable), but she could not claim to perform higher quality services.

The other area in which the Model Rules codify the principles set forth in the Supreme Court cases has to do with the proscription against solicitation. This proscription does not extend to potential chents with whoin the attorney has had a "prior professional relationship." ${ }^{113}$ This is significant because, presuinably, in most departing-attorney scenarios the attorney leaving the firm will have performed work for the chent in the past. For such attorneys, the broad rule against "solicitation" would not apply. These attorneys could offer their services to the chent, even on a known pending inatter, so long as they make no false or misleading representations.

Where a departing attorney has not previously enjoyed a professional relationship with a firm chent, the rule against solicitation would apply. Thus, she could not contact the chient, offering her services. The attorney could, however, send out announceinents introducing her new practice and providing other general information about the practice, such as the types of services offered and the basis on which fees would be determined. ${ }^{114}$

In summary, the profession's ethical rules codify, in part, the scope of proper coinpetition for firm chents by departing attorneys, and thus inform the inquiry of whether an interference was "improper." Part II discusses how courts have applied the interference tort in the departing attorney context, and illustrates the utility of the ethical rules in determining tort hability.

\section{II}

\section{LIABILITY FOR INTENTIONAL INTERFERENCE WITH ECONOMIC RELATIONS IN THE LEGAL PROFESSION}

Only two reported cases have addressed an attoruey's hability for intentional interference with economic relations between his former firm and a firm chent. Despite the relative paucity of case law on the subject, the recent phenoinena of lateral movement of attorneys and the heightened coinpetition for legal business magnify the potential problein. ${ }^{115}$ One case, holding departing attorneys liable to their former firm for intentional interference with contractual relations, is useful for its analysis of the issue. In the other case, the hability issue was raised, but not resolved by the court; nonetheless, the case provides a factual context for

113. Id. Rule 7.3.

114. The Model Rules regard general information of this sort as "advertising." See id. Rule $\mathbf{7 . 2}$ comment.

115. See supra notes $1-5$ and accompanying text. 
developing an appropriate basis for liability, and also identifies those factors which should not be considered in assessing interference tort liability. Since the firm in each case had a contingency fee contract with its client, the alleged interference gave rise to claims of intentional interference with existing contractual relations. However, since contingent fee contracts (as well as all otlier lawyer-client contracts) are terminable at will, ${ }^{16}$ the probleins raised by these cases apply as well to situations involving interferences witlı prospective economic relations between the firm and tlie client. ${ }^{117}$

\section{A. Adler, Barisl, Daniels, Levin \& Creskoff v. Epstein}

In Adler, Barish, Daniels, Levin \& Creskoff v. Epstein, ${ }^{118}$ several associates leaving the plaintiff law firm sent aimouncements to firm clients informing thein that they were forming a partnership and that the clients were free to terminate their relationship with the firm and be represented by the associates. The associates also sent blank change of attorney forms to the clients, all of whoin liad existing contingent fee contracts with the law firm. ${ }^{19}$ The firm brouglit an action against the former associates for mtentional interference witll contractual relations and souglit an injunction preventing the former associates from contacting the firm's clients. The trial court granted the requested relief, concluding tliat the associates had "engaged in illegal solicitation in coinplete and total disregard for the Code of Professional Responsibility' and had thereby 'tortiously interfered with the contractual and business relations that exist between Adler, Barish and its chient." "120

The associates appealed, and the Superior Court of Pennsylvania reversed and dissolved the injunction. ${ }^{121}$ The court, "[b]alancing the coinpeting interests delineated by section 767 of the Restatement of Torts," held that the associates' conduct was privileged. ${ }^{122}$ The court stated that allowing tlie associates to contact the firm's clients might further significant interests of the clients, which it equated with the policy

116. See, e.g., Fracasse v. Brent, 6 Cal. 3d 784, 790-91, 494 P.2d 9, 13, 100 Cal. Rptr. 385, 389 (1972) (noting that "the client's power to discharge an attorney, with or without cause, is absolute ... the chient may terminate that contract at will").

117. As explained above, interfering actors enjoy the "competition privilege" where the relationship interfered with is either a prospective relationship or a contract terminable at will. See supra text accoinpanying notes 54-56.

118. 482 Pa. 416, 393 A.2d 1175 (1978), cert. denied, 442 U.S. 907 (1979).

119. Id. at $421,393 \mathrm{~A} .2 \mathrm{~d}$ at 1178 .

120. Id. at $423,393 \mathrm{~A} .2 \mathrm{~d}$ at 1178 (quoting the trial court).

121. 252 Pa. Super. 553, 566-67, 382 A.2d 1226, 1228 (1977).

122. Id. at 566,382 A.2d at 1233 (referring to the RESTATEMENT OF TORTS $\$ \$ 766-767$ (1939)). The Restatement no longer uses the term "privileged" in this context, but instead speaks of "improper" interferences. Compare ResTATEMENT of TORTS $\S 766$ (1939) with RESTATEMENT (SECOND) OF TORTS $§ 767$ (1979). 
underlying Bates: "the consumer's concern for the free flow of commercial speech." 123 The court also noted in dictuin that it had "difficulty accepting the . . . conclusion that [the associates'] conduct amounted to solicitation in a legal sense," since the associates did not seek to stir up litigation or additional legal work. ${ }^{124}$

The Pennsylvamia Supreme Court reversed, holding the regulation of communication between the associates and Adler, Barish clients constitutionally permissible and reinstating the trial court's decision in favor of Adler, Barish. ${ }^{125}$ The court found that the associates had "clearly violated" the Code of Professional Responsibility's "proscription agamst self-recommendation" by recommending their own employment even though the chents liad not sought their advice. ${ }^{126}$

Turning to the law firm's claim of intentional imterference with existimg contractual relations, the court determined that the sole dispute was wliether the associates' conduct had been "improper."127 Utilizing the Restatement approach, ${ }^{128}$ the court held the imterference to be improper. Focusing on clause (a) of section 767, "the nature of the actor's conduct," the court, in its opimion, stated that the associates had violated the state's disciplinary rules, thereby violating the " rules of the game' which society has adopted." 129 Moreover, the associates' conduct had adversely affected the imterests of the clients im making informed and rehable decisions, as well as the firm's mterest in maintaining tlie expectation of revenue without outside interference. ${ }^{130}$

Justice Mandermo, dissenting, considered injunctive relief to be "completely unwarranted." 131 $\mathrm{He}$ distinguished this case from Ohralik since there had been no "coercive in-person solicitation ... no false and imisleading stateinents which would confuse, deceive, or mislead prospective chents," and the associates "did not attempt to motivate these clients to stir up hitigation."132 Justice Manderino concluded that the court's

123. 252 Pa. Super. 553, 565, 382 A.2d 1226, 1232 (1977) (quoting Bates v. State Bar of Arizona, 433 U.S. 350, 363 (1977)).

124. Id. at 561-62, 382 A.2d at 1230-31. The court noted, however, that even if the associates' conduct did amount to "solicitation," their conduct could nonetheless be privileged. Id. at 562, 382 A.2d at 1231. One judge, concurring in the judgment and relying on Bates, felt that the injunction should be dissolved because it infringed upon the associates' first amendment rights. Id. at 568,382 A.2d at 1236 (Spaeth, J., concurring).

125. 482 Pa. 416, 428, 435, 393 A.2d 1175, 1181, 1186 (1978), cert. denied, 442 U.S. 907 (1979).

126. Id. at $425,393 \mathrm{~A} .2 \mathrm{~d}$ at $1179-80$.

127. Id. at $431,393 \mathrm{~A} .2 \mathrm{~d}$ at 1183.

128. See RESTATEMENT (SECOND) OF TORTS $\$ 767$ (1979) (listing those factors to be considered in determining whether an interference is "improper").

129. $482 \mathrm{~Pa}$. at 433,393 A.2d at 1184 (quoting Glenn v. Point Park College, $441 \mathrm{~Pa} .474,482$, 272 A.2d 895, 899 (1971)).

130. Id. at $434,393 \mathrm{~A} .2 \mathrm{~d}$ at $1184-85$.

131. Id. at 441, 393 A.2d at 1187 (Manderino, J., dissenting).

132. Id. at 441, 393 A.2d at 1187-88 (Manderino, J., dissenting) (einphasis in original). 
holding not only denied the associates their first amendment rights, but also deprived the clients of truthful information about their rights. ${ }^{133}$

\section{B. Rosenfeld, Meyer \& Susman v. Cohen}

In Rosenfeld, Meyer \& Susman v. Cohen, ${ }^{134}$ the plamtiff law firm had a contingent fee contract with a client regarding a major patent antitrust action. The defendants were two former hitigation partners of the firm who had handled the suit from its inception. ${ }^{135}$

Approximately five years after the firm began work on the case, the defendants came to believe that the case would settle for between $\$ 20$ million and $\$ 50$ million, or if tried, result in a judgment of approxiinately $\$ 100$ million before trebling. ${ }^{136}$ At that time, the defendants demanded that their partnership allocations from the case be increased and threatened withdrawal from the firm if their demands were not met. ${ }^{137}$ After negotiations between the firm and the partners proved fruitless, the defendants withdrew from the firm and formed their own partnership. One month later, the client $\mathrm{m}$ the antitrust case discharged the firm and retained the defendants as attorneys in the action.

The client and the defendants signed a contingent fee contract whereby the defendants would receive approximately twice what they would have received as partners in the firm, and the chent would pay substantially less than what it would have paid the firm under the original agreement. ${ }^{138}$ The firm brought suit against the former partners and the client, alleging among other things, breach of fiduciary duty, interference with contractual relations by the former partners, and conspiracy by the former partners and the chient to interfere witli the contractual relations between the chient and the firm. ${ }^{139}$

The trial court found that the firm had failed to state a cause of action for breach of fiduciary duty. ${ }^{140}$ With respect to the tort cause of action, the court confined the firm's argnment to proving active interfer-

133. Id. at $441,393 \mathrm{~A} .2 \mathrm{~d}$ at 1188 (Manderino, J., dissenting).

134. 146 Cal. App. 3d 200, 194 Cal. Rptr. 180 (1983).

135. The law firm was a dissolved at-will law partnership consisting of the defendants and seventeen other partners. Id. at 208, $194 \mathrm{Cal}$. Rptr. at 184.

136. Id. at 209, $194 \mathrm{Cal}$. Rptr. at 185.

137. While the defendants devoted substantially all of their time to the case during the five year period, they continued to draw their partnership share of firn profits-approximately $\$ 800,000$ combined-even though the case produced no revenue during this period. Id.

138. Id. at 210-11, $194 \mathrm{Cal}$. Rptr. at 185-86.

139. Id. at 211-12, $194 \mathrm{Cal}$. Rptr. at 186-87.

140. Id. at 213, $194 \mathrm{Cal}$. Rptr. at 187. The court held that, because the law firm was an at-will partnership, the forner partners had an absolute right to dissolve the partnership, even in bad faith. Id. The court also held that the former partners could not be held hable for breach of fiduciary duty to wind up unfinished partnership business, reasoning that the client's discharge of the firm precluded hability. Id. at 217, $194 \mathrm{Cal}$. Rptr. at 190. 
ence, that is, that the former partners had told the client they were essential to the case and that the firm could not adequately represent the client's interests. At the close of the firm's case, the trial court granted the former partners' motion for a nonsuit. ${ }^{141}$ The court also dismissed the cause of action against the chent for conspiracy to interfere with its own contractual relations. ${ }^{142}$

The Califorma Court of Appeal reversed as to both the fiduiciary duty and the tort causes of action. ${ }^{143}$ With respect to the tort cause of action, the court held that the trial court had erroneously limited the firm's proof of interference with contractual relations, since "[i]n California, pleading ultimate facts of interference, such as advising, counseling and persuading termination of a contract, is sufficient to state a cause of action for interference witli contract." 144 The court pointed out that the firm had successfully pleaded these ultimate facts and concluded that the firm should have the opportunity to substantiate its claim at trial. ${ }^{145}$

Finally, the court held that neither the attorney-chent relationship nor the statute relating to publications made in the course of judicial proceedings granted the former partners an absolute privilege to interfere with the firm's contract with its clients. ${ }^{146}$ With respect to the attorneyclient privilege, the court noted that the privilege applies only where the relationship between the parties involves the type of interests that the privilege is intended to protect, and where the advisor's intent in inducing the breach is proper, that is, not self-serving. ${ }^{147}$ The court then stated that the existence of a particular relationship between two parties is only one factor to be considered in determining whether the interference was "improper," 148 and that the inquiry "is peculiarly a question for determination by the trier of fact."149

Thus, while the tort liability issue was raised in Rosenfeld, the court was unable to decide the question as certain factual issues remained unresolved due to the procedural posture of the case (nonsuit at the trial

141. Id. at 212, $194 \mathrm{Cal}$. Rptr. at 187.

142. Id.

143. Id. at 208, $194 \mathrm{Cal}$. Rptr. at 184 . With respect to the cause of action for breach of fiduciary duty, the court held that the former partners could be held liable for bad faith dissolution of the law firm partnership and for not winding up unfinished business of the firm. Id. at 212-20, $194 \mathrm{Cal}$. Rptr, at 187-92.

144. Id. at 221, 194 Cal. Rptr. at 193.

145. Id. at 223, $194 \mathrm{Cal}$. Rptr. at 194. The California standard for intentional interference with contract (or prospective economic relations) as stated by the Rosenfeld court is identical to the Restatement standard-to be actionable, an interference must be "improper." Id. at 230, $194 \mathrm{Cal}$. Rptr. at 199.

146. Id. at 227-34, $194 \mathrm{Cal}$. Rptr. at 197-202.

147. Id. at 228, 194 Cal. Rptr. at 198.

148. Id. at 230, 194 Cal. Rptr. at 199. The court set out the approach advanced by RESTATEMENT (SECOND) OF TORTS $§ 767$ (1979).

149. $146 \mathrm{Cal}$. App. 3d at 230, $194 \mathrm{Cal}$. Rptr. at 199. 
court level). Nonetheless, Rosenfeld is useful to this analysis for more than its factual setting. First, the court's announced standard mirrors that of the Restatement-requiring that an interference be "improper," yet not giving much guidance in defining that term. Second, the court rejected the trial court's attempt to narrow the types of conduct by which the plaintiff-firm could prove that the defendants had "improperly" interfered with the relationship. As will be developed later, this Comment argues that narrowing the impropriety inquiry is precisely the approach courts should take. ${ }^{150}$

\section{Problems Raised by Adler, Barish and Rosenfeld}

The decisions in Adler, Barish and Rosenfeld illustrate the Restatement's problem of uncertainty. Both courts employed the Restatement factors for determining whether the departing attorneys' conduct was "improper," yet they gave little insight into how the factors, taken together, should be considered. The Restatement itself acknowledges the case-specific nature of the inquiry, ${ }^{151}$ but offers that "factual patterns develop and judicial decisions regarding them also develop patterns for holdings that begin to evolve crystallized privileges or rules defining conduct that is not improper." 152 In the case of departing attorneys, a consistent factual pattern can be discerned. Consequently, a narrower, more concrete test for tort hability can be developed that furthers the policy goals of the tort and sends a clear message to affected parties. Such a test would reduce the problem of uncertainty by eliminating consideration of irrelevant and inconclusive factors.

The existence of fiduciary relationships in a case, such as in Rosenfeld, illustrates another potential problem. Where the breach of such duties is also at issue, there is the danger that a court may analyze the dispute as a breach of a fiduciary duty rather than as an interference tort in determining whether the conduct is "improper." Because the duties are distinct, and speak to different values, this is not desirable. Developing a test that narrows the courts' focus in determining liability would serve the goal of foreclosing courts from considering issues which are more properly relevant to different legal duties. The following Part explains how a more narrowly focused test can be developed for the departing-attorney situation, develops the test, and suggests its benefits.

150. See infra Part III.

151. RESTATEMENT (SECOND) OF TORTS § 767 comment b (1979).

152. Id. 
III

\section{Developing a New Test}

Adherence to the law is difficult when the boundaries defining perinissible conduct in a given situation are unclear. This is especially true where the courts speak of the standard in such vague terms as " the rules of the game." "153 It is true that soine standards, inost notably the negligence standard, reinain fact-oriented and are generally determined on a case-by-case basis. Yet the hability standard for the interference tort purports to be inore precise than the general "reasonableness" standard of negligence. The Restatement narrows somewhat the factors to be considered, but where the relevant factors can be further pared down without sacrificing any values enbodied in the tort duty, this should be done.

Another relevant distinction between the duty of ordinary care (negligence) and the interference tort is that the latter is an intentional tort. Where intent is a necessary element, a well-defined duty of care will benefit parties because they will be able to consciously order their behavior to the legal requireinent. Hence, a nore concrete standard of liability is desirable.

As was explained above, ${ }^{154}$ the current standard has two main problems. First, it is uncertain what factors will be dispositive of the liability issue-particularly, what will determine whether an interference was "iinproper." Second, the scope of factors that a court will consider is uncertain since courts soinetimes consider factors that are relevant to other legal duties-such as the breach of a fiduciary duty. The interference tort is not designed to enforce the duties partners owe one another as partners; its focus is on the duty owed by competitors.

The following Section will show why, in determining whether an interference was "inproper" in the departing-attorney context, it is appropriate to focus exclusively on the conduct of the departing attorney, rather than any of the other factors listed by the Restatement. The next Section discusses how the propriety of an attorney's conduct can be evaluated. It then develops a new test which asks whether the attorney's conduct was either independently unlawful or violative of ethical rules regulating lawyer commumications. The new test will then be coinpared to present law, demonstrating how the test would be an improvement. Finally, possible objections to the new test will be addressed.

153. See Adler, Barish, Daniels, Levin \& Creskoff v. Epstein, 482 Pa. 416, 434, 393 A.2d 1175, 1184 (1978), cert. denied, 442 U.S. 907 (1979).

154. See supra Part II, Section C. 


\section{A. "Crystallized Patterns" in the Departing-Attorney Context Make the Attorney's Conduct the Appropriate Focus}

As previously noted, while the Restatement does not give definite substance to the meaning of "improper," it does recognize that factual patterns develop for given situations that may allow for the development of a more concrete test. ${ }^{155}$ An examination of the Restatement factors for determining whether an interference is "improper," together with an examination of the factual patterns representative of the departing-attorney situation, demonstrate that im determining liability, the focus should be upon the nature of the attorney's conduct. Such a focus is proper because in the departing-attorney context, the other factors laid out in the Restatement do not vary in a legally significant ma1mer and thus will never be determinative in a given case. A brief consideration of the fac: tors will bear out this point.

The "actor's motive"156 in the departing-attorney situation is primarily economic, altliough the attorney may also liave a desire to take care of the chent's legal interests. Whether the departing attorney is purely greedy or purely conscientious, however, is essentially irrelevant to this imquiry. By way of contrast, this fact is relevant when a party's sole motive is to mjure the other party. Since the departing attorney seeks to lure away clients for economic reasons, and not to harm her former firm, the motive issue is irrelevant and need not be addressed in assessing liability.

The "interests of the other,"157 that is, the interests of the law firm, may be an existing contract terminable at will ${ }^{158}$ or prospective economic relations, such as an ongoing business relationship. ${ }^{159}$ While the law firm's interest may take either of these forms, there is no legal significance to the distimction between the two in this context. In either case, the firm maintains only a hope of future relations. Here, one of the "crystallized privileges" of the Restatement is relevant. All other factors being neutral, the pohicy of free competition justifies interference with contracts terminable at will and prospective economic relations. ${ }^{160}$ That being so, resort must be had to the other factors; this factor will not be outcome determinative. A new test need not address it.

Similarly, "the actor's interest,"161 that is, the departing attorney's

155. Restatement (SECOND) OF TORTS § 767 comment b (1979).

156. Id. § 767(b).

157. Id. \& 767(c).

158. All law firm contracts are terminable at will. See supra note 116.

159. An "ongoing business relationship" might be further broken down into arrangements where a firm is on retainer, and those where the firm works on an hourly basis. In both cases, the contracts are terminable at will.

160. RESTATEMENT (SECOND) OF TORTS $§ 768$ (1979).

161. Id. $\$ 767(\mathrm{~d})$. 
interest, will always be prospective, since she will not have an existing contract with the chent. ${ }^{162}$ Viewed in conjunction with the law firm's interest (prospective relations or contract terminable at will), interference by the attorney would normally be justified as "coinpetition," since the two interests are legally equivalent. ${ }^{163}$ Therefore, this factor is inconclusive.

The "social interests"164 involved in this situation also do not vary: there are interests both in allowing the firm to maintain existing relations and in allowing the departing attorney to acquire new relations (or continue existing relations under new terms). These interests are subsumed in the "competition privilege." Thus, they will not, of theinselves, be outcoine determinative. Also, there is an interest in affording the client the opportunity to be represented by the attorney of her clioice. This can only be achieved by encouraging "the free flow of commercial information." 165 Fnially, there is an interest in preventing inducement by unlawful means, such as fraud, slander, or battery. What is important to note witll respect to all of these interests is thiat they find expression.in the respective sources of liability (tort and criminal law, ethical rules) of the proposed test. In other words, the respective bodies of law which serve as the sources of hability in the proposed test recognize and serve these interests. ${ }^{166}$ Hence, adoption of the proposed test would take cognizance of the social niterests affected in the departing-attorney situation snice to the extent those interests have any effect on the outcoine of any case, they are subsumed in the conduct factor of the proposed test.

The "proximity . . . of the actor's conduct to tlie interference"167 does not vary in any significant manner in the departing-attorney context: the departing attorney induces tlie client to establisli relations with her, ratlier than to sever relations witli the firm, altliougli the latter is a necessary consequence of the former. ${ }^{168}$ In this context, the relationship

162. In situations not involving departing attorneys, this factor may be relevant under the Restatement test because the party interfered with might have an existing contract (not terminable at will), and thus would have a superior claim to protection than an interfering party who enjoyed only a prospective interest.

163. The "privilege to compete" is, however, more circumscribed in the attorney-client setting (than in other commercial settimgs) due to ethical restraints on how attorneys may compete for business. For a discussion of the ethical rules and case law, see supra notes 64-114 and accompanying text.

164. RESTATEMENT (SECOND) OF TORTS $§ 767(\mathrm{e})(1979)$.

165. Bates v. State Bar of Arizona, 433 U.S. 350,365 (1977).

166. The ethical rules, and the cases placing limits upon thein, balance the potential dangers of unrestrained solicitation against the benefits of increased competition through broader publicity. See id. Tort and criminal law represent the balance strnck between freedom of action on the one hand and personal interests on the other.

167. RESTATEMENT (SECOND) OF TORTS $\$ 767$ (d) (1979).

168. The Restatement is especially unclear about how this factor should be evaluated or even what it ineans for an interference to be a "direct" versus "indirect" consequence of a person's 
will always be very direct since the departing attorney is taking a known client from her former firm. For this reason, liability will not turn on this factor. This factor will only be considered in those situations where the relationship between the actor's conduct and the interruption of economic relations is so attenuated that tort hability is inappropriate. ${ }^{169}$ Because the attenuated-relationship situation is never present in the departing-attorney context, this factor is irrelevant and thus inay be ignored im developing a new test.

Finally, analysis of the "relations between the parties" 170 will not, of itself, resolve the question of whether an interference was "improper." The departing attorney will bear some fiduciary obligation (as an advisor) to the client. Imitially, then, it may seem that the Restatement's "crystallized privilege" of "[a]dvice as proper or improper"171 may be relevant. The firm, however, will also bear a fiduciary obligation to the client. Ultimately, the balancing of these competing interests requires one to look to the attorney's conduct to determine which interest should prevail. This is so because the ethical rules-which regulate attorney conduct-provide the only basis for determining whether, in a given situation, a fiduciary relationship justifies self-promotion.

Another relevant relationship in this situation is that between the attorney and the firm. The attorney will have a fiduciary relationship to the firm, either as an agent (im the case of an associate) or as an expartner. Assessing the appropriate consequences of this relationship requires one to look at the attorney's conduct.

As demonstrated above, six of the seven factors delineated by the Restatement for determining whether an interference is "improper" are either totally inconclusive in the departing-attorney situation or are inconclusive except to the extent they are implicitly factored into "the actor's conduct." These factors can, therefore, be eliminated from a liability standard in the departing-attorney context. Thus, it is the conduct of the departing attorney which does and should resolve the inquiry of whether the attorney will be held liable for intentional interference with contractual relations or prospective economic relations.

\section{B. Sources of Liability Under the Proposed Test}

There are two sources of standards for evaluating whether an attor-

conduct. Nonetheless, since this factor does not vary in the departing-attorney context, the factor will not determine hability.

169. An example of this type of situation might be where $A$ contracts to sell $B$ a car. $B$ no longer needs to share rides to work with $C$, and thus severs that relationship. The proximity of $A$ 's conduct to $B$ 's relationship with $C$ is such that $A$ is not liable to $C$ for interference with contractual relations, even if $A$ knew of $B$ 's relationship with $C$.

170. RESTATEMENT (SECOND) OF TORTS $§ 767(\mathrm{~g})$ (1979).

171. Id. § 772; see supra text accompanying notes $59-62$. 
ney's conduct follows recognized rules of behavior: tort and criminal law; and rules of professional conduct. These standards, in turu, are readily ascertainable and codify the societal rules of fair coinpetition which the interference tort seeks to address. ${ }^{172}$

The first source of liability under the proposed test attaclies where the underlying behavior (that is, means of interference) of the attorney is independently wrongful. "Wrongful" in this sense includes intentional torts and crimes. ${ }^{173}$ For example, the interfering party may, through her overtures, libel or slander the firm. The interferer might also effect the interference fraudulently, by misrepresenting to tlie client what a change of attorneys would entail. ${ }^{174}$ It seems clear that under any test of liability, suclı an interference should be regarded as "improper." For example, even in the Restatement sections defining "crystallized privileges" exempting interferences from tort liability, ${ }^{175}$ the privileges do not apply where the underlying behavior of tle interfering party is "unlawful." Common sense tells one that, lowever viewed, independently unlawful conduct causing interference with another's economic relations constitutes an improper form of economic competition, and thus should subject the interfering party to tort liability. ${ }^{176}$

172. Using the terminology of RESTATEMENT $\$ 767$ comment $b$, the "factual pattern" for the departing-attorney situation has "crystallized," which permits compressing the $\S 767$ balancing test into the proposed test.

173. Because the interference tort is an intentional tort, only intentional torts, such as libel, slander, or fraud inay serve as the basis for wrongfnl conduct. Thus, for example, a negligent misrepresentation could not subject a party to hability for intentional interference.

174. It bears noting that where the interference is effected by unlawful means, such as slander or fraud, the client inay also have a cause of action for that conduct, quite apart from the interference tort. In the case of fraud, the law firm would not have a direct action against the lawyer for the fraudulent representation. The client, however, would have a cause of action against the lawyer for fraud.

175. Restatement (SECOND) OF TORTS $\$ \$ 768-774$ (1979).

176. One comınentator, arguing for limitation of the interference torts solely to instances where wrongful means have becn used, explains how the imposition of hability in such cases carries out the underlying policy of the tort. Perlman, supra note 12, at 69. According to Professor Perlinan, the interference tort historically provided an alternative to a claim based directly on the underlying unlawful behavior, where the loss was purely economic. Id. Many actions on the part of an actor might cause economic loss to another party, such as offering a lower price on a competing good, thereby diverting potential business from the other. It is clear, however, that not all such actions causing economic harm to another should subject the actor to tort hability. On the other hand, it is also true that actors should not always be inmune from liability to others for causing purely economic harm. The difficult distinction is between injuries flowing "directly" from the actor's conduct and those which are more "indirect": "[b]y requiring the plaintiff to show intent by the defendant to interfere with a particular contract, the tort distinguishes the plaintiff's loss from injuries resulting inore indirectly from the defendant's act." Id. at 76 . The torts-with the intent requirement-thus provide a convenient limit to compensable economic losses.

Professor Perlman proposes an "unlawful means" test in order to "distinguish recoverable losses from inore indirect losses so that some workable limits on hiability may be maintained." Id. at 78. Professor Perlman argues that "inducer tort liability" for interference by otherwise lawful means interferes with economic efficiency. To him, it is "startling that a doctrine of this sort is 
There is, however, one important exception to the "independently wrongful" source of hability: A breach of fiduciary duty by the departing attorney to her former firm would not be considered a proper basis for liability. ${ }^{177}$ There are several reasons for this. First, whether the departing attorney lias breached a duty of loyalty owed to her former firm as the result of her status as an ex-partner or as an ex-employee is not relevant to whether she has breached a duty as a competitor. Second, utilizing a breach of fiduciary duty as a basis for finding interference tort liability would result in undesirable overlap. Partnership law ${ }^{178}$ and agency law $^{179}$ both contain restrictions on the extent to which a fiduciary inay compete with her principal. Enforcing these restrictions through the interference tort risks confusion and double liability. Thus, breaches of fiduciary duties should be kept apart from tort liabihity.

The second source of liability under the proposed test arises when the attorney's conduct violates the ethical rules which regulate the professional conduct of attorneys in their relations with clients and potential chents. Such regulations are normally promulgated by state bar associations and are often identical to model regulations drafted by the American Bar Association. Ethical rules represent a codification of minimum acceptable standards of behavior for inembers of the bar with respect to their relations witl one another, with the general public, and with the

superimposed on an economic order committed to competition." Id. Thus, only those interferences in which the interfering party's underlying conduct is "unlawful" should give rise to liability.

This Comment agrees that the interfering party should be subject to tort liability when the underlying conduct of the interfering.party is independently wrongful. It seems plausible, however, that some situations might call for hability even where the underlying conduct is not strictly "uulawful." If one identifies economic efficiency as the sole goal of the tort, Professor Perlman's argument is persuasive. If, however, the interference tort is viewed as serving other policies, such as the protection of contractual integrity, then one might favor imposing liability even where the actor's conduct was not independently tortious or criminal im nature. This Comment argues that such a view is morc appropriate, and that if the aim is to prevent "improper" interferences, liability should attach to one who interferes with a contract by unethical ineans. The proposed test is thercfore somewhat broader than Professor Perlman's in that it imposes liability for some conduct which is not independently tortious or criminal. Also, while Professor Perlman, on efficiency grounds, favors scrapping the entire present regime, this Comment works within the existing framework and finds that the framework itself provides the solution.

177. The proposed test makes this distimction even though, strictly speaking, a breach of fiduciary duty is a "tort" since it is "a civil wrong, other then breach of contract, for which the court will provide a remedy in the forin of an action for damages." Prosser AND KeEton, supra note 11, $\S 1$, at 2. A breach of a fiduciary duty, however, is a special kind of tort, since it depends upon the existence of a relationship of trust between the tortfeasor and the plaintiff. The unique nature of fiduciary duties is underscored by their omission from the RESTATEMENT (SECOND) OF TORTS (1979) and by the Amcrican Law Institute's special treatment of fiduciary duties in the Restatement (SECOND) of Trusts (1957), the Restatement (SECOND) of Agency (1958), and the UNIFORM PARTNERSHIP ACT.

178. UNIFORM PARTNERSHIP ACT $\$ 37$.

179. REstatement (SECOND) OF AGENCY $\$ \S 388,393$ (1958). 
judicial system. ${ }^{180}$ Violation of such rules may subject an attorney to disciplinary action. ${ }^{181}$

The Restatement recognizes the relevance of "recognized ethical codes for a particular area of busimess activity" in evaluating the nature of the interfering party's conduct. ${ }^{182}$ Such ethics are particularly relevant where, as $\mathrm{m}$ the legal profession, the recognized ethics have been codified by statutes that impose pumitive sanctions for violations. Reference to ethical codes will help to analyze the nature of the departing-attorney's conduct. If the conduct indicates a breach of ethical codes, such as improper commumication directed to the chent, it will be "improper" under the Restatement test. Thus, this part of the proposed test reaches the same result as should obtain under the Restatement approach.

As indicated earher, ${ }^{183}$ the relevant ethical rules in this situation are those prohibitimg false and misleading statements, ${ }^{184}$ and prohibiting solicitation where the attorney has had no prior professional relationship with the potential chent. ${ }^{185} \mathrm{~A}$ departing attorney can stay within these himitations by carefully tailoring her oral and written communications to chents in a manner allowed by the ethical rules as previously set forth in Part I, Section B.

\section{The Benefits of the Proposed Test}

\section{The Proposed Test Alleviates the Problem of Uncertainty}

As imdicated earher, a major problem in the apphication of the interference tort to the departing-attorney context is its uncertainty: attorneys are unsure of how they may advise a client with respect to their imminent departure from the firm without exposing themselves to tort hability. As a consequence, botl attorney and client suffer. The attorney may behave too cautiously, thus limiting her legitimate interest in prospective future relations with clients sle lias served for some time. In turn, the client inay suffer by being effectively deprived of infornation necessary to inake an informed decision about low ler legal interests might best be served. In suin, the attorney's caution may translate to inaction on the part of the client.

The proposed test will go a long way toward alleviating the problem of uncertainty. An attorney faced with an imminent departure from her firm will have relatively well-defined standards of behavior to consult:

180. See Model Code of Professional Responsibility Preliminary Stateinent (1980).

181. The most frequent disciplinary procedure entails hearings before a state disciplinary board and possible appeal to the state courts.

182. RESTATEMENT (SECOND) OF TORTS $\$ 767$ comment c (1979).

183. See supra notes $87-114$ and accompanying text.

184. Model Rules of Professional Conduct Rule 7.1 (1983).

185. Id. Rule 7.3. 
tort and criminal law, and state ethical rules. ${ }^{186}$ Thus, the attorney who carefully tailors her communications with clients regarding her departure need not fear liability for intentional interference.

Conduct that is independently unlawful will subject the attorney to liability for intentional interference (as well as any other independent tort or crime that niay have been committed). As for the evaluation of conduct on the basis of ethical rules, truthful, nonnisleading statements of fact will pass scrutiny. ${ }^{187}$ Representations as to the comparative quality of the lawyer's services or those of the former firm will clearly be improper, as will any other representation that cannot be factually verified. ${ }^{188}$ Statements likely to create unjustified expectations in the potential client, sucl as the promise of a favorable outcome, will also be improper. ${ }^{189}$ Where the attorney las no prior professional relationship with the potential client, she nray not sohcit business by offering services to the chent. ${ }^{190}$ Where there has been a prior professional relationship, this prohibition does not apply; thus, the attorney would be permitted to offer lier services to the client. ${ }^{191}$ If the attorney follows these guidelines in seeking to represent the firm client, sle need not fear liability for intentional interference.

The increased clarity of the proposed test will benefit clients as well. Since it is likely that clients will receive the maximum amount of permissible information from departing attorneys, they will be able to make better informed clioices as to representation. Additionally, the restraints imposed by the rules of professional conduct will also ensure thiat clients will not be subjected to the types of dangers posed by false or misleading statenients and solicitation by unknown persons.

\section{The Proposed Test Appropriately Limits the Scope of Inquiry}

The interference tort seeks to regulate the economic beliavior of parties in an economy based on free conipetition. The tort iniposes a duty on competitors to compete fairly by not improperly interfering with their competitors' economic relations. The proposed test addresses the policy of preventing improper interferences by requiring all lawyers, as competitors in the legal market, to follow uniform guidelines. At the same time,

186. A possible objection is that tort and criminal law are not themselves perfectly clear. The proposed test, however, does not purport to provide crystal-clear guidelines for behavior. What it does attempt to do is make the test for liability clearer than the present amorphous test. In this regard, the limits of the tort and the criminal law are at least doctrinally clearer than the present standards for the interference tort. With respect to criminal law, it is by definition quite clear: Due Process requires it be so.

187. Model Rules of Professional Conduct Rule 7.3 (1983).

188. Id.

189. Id.

190. Id.

191. Id. 
the narrowed focus of the proposed test eliminates concerns more properly resolved by bodies of law that impose different duties on competing lawyers. For example, in analyzing the departing attorney's conduct, attention will not be given to whether she has breached a fiduciary duty to the former firm. Whether the departing attorney has breached a duty as an ex-partner or as an ex-associate, as opposed to a duty as a competitor, is relevant to partnership or agency law, not the interference tort. ${ }^{192}$ The limited inquiry of the proposed test precludes judges from considering the fiduciary aspect of the situation, a temptation which is particularly strong where the court feels that "something" is amiss even though the elements of a breach of a fiduciary duty cannot be established. Thus, the proposed test precludes use of the interference tort as a residual source of hability for all intuitively "bad" conduct.

The proposed test's narrowed focus similarly forecloses courts from considering other factors which are teinpting to consider, but which are ultimately beyond their competence. The best example of such an inappropriate factor is the determination of who actually represents the chent. There is no clear way to resolve this issue, since the chent einploys "the firm," but inay be drawn to the firm in order to be represented by the departing attorney. The Model Rules do not address this issue. Yet, where liability depends solely on the amorphous concept of whether an action was "improper," courts may intuitively address this issue. The proposed test would eliminate such inquiries froin bearing on the issue of liability.

\section{Potential Arguments Against the Proposed Test}

\section{Ethical Rules as a Standard of Liability}

Several objections might be raised to using state ethical rules as a standard of hability. First, it may be argued that the legal profession is self-regulating (that is, it proinulgates the rules which regulate it), thus raising a conflict of interest problem. Second, it may be contended that the rules regulating attorneys are theinselves unclear and relatively weak. Finally, it inay be argued that the ethical rules are an inappropriate standard for tort hability since they were not intended for such a purpose.

There are two answers to the self-regulation argument. First and foremost, state bar associations (those promulgating the rules) have been, if anything, less wilhing than the courts to grant freedom of action to

192. For example, whether the departing attorney has failed to wind up unfinished partnership business is relevant to partnership law; whether she has misappropriated firm "property," such as goodwill, is relevant to agency law. These bodies of law deal exclusively with their respective discrete duties, and they set forth specific standards for demonstrating a breach of those duties. A breach of one of these duties should not be relevant to the interference tort, since the interference tort's focus is on an actor's duty as a competitor, not as a fiduciary. 
attorneys in their efforts to procure business. Traditionally, the legal profession has strictly regulated lawyer communications with potential chents; it is only since Bates, when the Supreme Court held, on constitutional grounds, that state rules of professional conduct regulated such commumications too strictly, that state bar associations have promulgated more permissive regulations. ${ }^{193}$

The second answer to the self-regulation objection is that, as far as any problem of conflict of imterest goes, lawyers sit on both sides of the dispute. Both the mjuring and mjured parties are attorneys or associations of attorneys. Hence, the "private" nature of the action obviates any danger of self-interest.

As to the objection that present regulations are unclear and relatively weak, it may be true that there are some gray areas in the regulations regarding permissible communications, that is, what the line is between permissible "advertising" and prohibited "solicitation." 194 However, in the context of an existing client of a law firm, the line is actually quite clear. Where the attorney has had a prior professional relationship with the chent (while the attorney was still at the firm), she is not subject to the rule against solicitation; only the rule against false or misleading statements. Where there is no prior relationship, the attorney may not take the initiative in offering services to the client. Announcements settimg forth general information about the attorney's new practice may be sent, and, of course, the rule against false or misleading statements applies. The most problematic "gray area" cases, those involving mailings directed toward specific persons in need of specific services, are not relevant im this context.

As for the alleged weakness of the regulations, present regulations are in fact quite stringent against false and misleading statements and solicitation of clients. Indeed, they go as far as is constitutionally permitted, as the Supreme Court's scrutiny of them in a series of cases demonstrates. ${ }^{195}$ In sum, state regulations provide stringent guidelines for the conduct of attorneys. Also, the application of such guidelines to the departing-attorney context does not pose constitutional probleins. ${ }^{196}$

193. For a discussion of Bates v. State Bar of Arizona, see supra text accompanying notes 67-74.

194. For a discussion of In re Koffler and Kentucky Bar Ass'm. v. Stuart, see supra text accompanying notes 99-102.

195. See Zauderer v. Office of Disciplinary Counsel, 471 U.S. 626 (1985); In re R.M.J., 455 U.S. 191 (1982); Ohralik v. Ohio State Bar Ass'n., 436 U.S. 447 (1978).

196. It should be noted that using state ethical rules as the standard for a private cause of action does not raise the types of problems raised by implying a private cause of action from a federal or state regulation. See, e.g., Cort v. Ash, 422 U.S. 66 (1975) (private cause of action not implied from Federal Election Campaigu Act, 18 U.S.C. § 610). In the latter situation, implying a cause of action may raise problems of conflict with the regulatory scheme. In contrast, using rules of professional conduct as a standard for an existing private cause of action does not enlarge or diminish the regulatory scheme. 
Finally, the proposed test's use of ethical rules as a basis for liability does not represent an attempt to enforce the ethical ideals of the legal profession through private hitigation. The ethical rules do not define "ethical" behavior, but merely define a minimum floor for ethical conduct. Thus, utilizing the ethical rules (as opposed to broader ethical "considerations" or principles) as a standard for evaluating conduct ainounts to enforcement of the minimal requirement of all attorueys, not of the ideal ethical model. Also, the interference tort proscribes "improper" interferences with economic relationships. "Improper" in the context of an attorney's economic relationships necessarily includes the question whether she improperly "solicited" business. Thus, in this particular situation, the legal duty not to interfere "improperly" is, in part, defined by the ethical duty not to "solicit" busmess. Consequently, in this situation it is appropriate to use the ethical rules as a source of legal hability. ${ }^{197}$

\section{A Separate Standard for the Legal Profession}

A fair objection to the proposed test is that it attempts to set up a separate standard of liability for the legal profession. This would seem to conflict with the pohicy to make laws uniforn and to develop general principles to govern all situations. The problem may appear even more acute given the distrust of the legal profession by some sectors of society.

This issue is a part of the famous Holmes-Cardozo debate over the specificity with which legal standards should be framed. ${ }^{198}$ Justice Cardozo argued that standards should be fornulated in general terins, thus allowimg consideration of relevant variables in any given case. ${ }^{199}$ Justice Holmes imphied that tests of hability should be stated in more concrete terins for a special class of cases, where there is, for example, only one

197. It is appropriate to use state ethical rules as a standard of liability for the interference tort notwitlistanding the admorition by the drafters of the Model Rules that "[v]iolation of a Rule should not give rise to a cause of action nor should it create any presumption that a legal duty has been breached." Model Rules of Professional Conduct Preamble (1983). This is because the possible underlying fear of the drafters-that the Model Rules miglit be used out of context as bases for causes of action-does not appear justified in the context of determining the liability of departing attorneys for intentional interference witl the former firm's relations witl its clients.

The drafters' concerns regarding using ethical rules as a source of legal liability are valid witl a tort sucl as legal malpractice, which takes into consideration many "subjective" factors, sucli as the appropriate duty of care, and in which the legal duty does not necessarily coincide with the etlical duty. The drafter's concerns, however, are not valid with the interference tort. Witl the interference tort, the basic standard of "improper" can be defined with relative objectivity by utilizing establislied guidelines of conduct. Additionally, the legal duty coincides with the ethical duty.

198. See Pokora v. Wabasl Ry. Co., 292 U.S. 98 (1934) (Cardozo, J.); Baltimore \& Olio R.R. v. Goodman, 275 U.S. 66 (1927) (Holmes, J.). The debate in these cases was over the specificity of the definition of the rcasonably prudent person standard in the context of railway crossings.

199. Pokora, 292 U.S. at 105-06. 
variable. $^{200}$ The latter approach has several characteristics that may be desirable: (1) it promotes uniformity (and thus predictability); (2) it takes value judgments away from the jury (or judge); and (3) it views law like a code, similar to the criminal law. ${ }^{201}$

The hability standard for intentional imterference in the departingattorney context should take the Holmes approach for several reasons. First, the premise underlying this approach is present: the departingattorney situation provides a "special class of cases." Second, the benefits of uniformity and predictability are especially important and useful in the context of an intentional tort since they enable parties to conform their behavior to the requirements of the law. Third, it is important in this context to narrowly define the duty smce there are potentially overlapping legal duties (agency or partnership with tort). Thus, the arguments in favor of Justice Holmes' view have special force in the departing-attorney situation.

A number of other aspects of the legal profession also favor applying a separate tort standard to it. First, the legal profession is a highly regulated industry; it has significant entry barriers (for example, the bar examination), and the means by which attorneys can compete for clients is restricted. ${ }^{202}$ Thus, special rules regulating competition within the industry already exist. Creation of a separate tort standard for such an industry allows recognition of such rules. A second factor is the fact that these restrictions have been codified. ${ }^{203}$ The codification of these standards makes it particularly useful to use these rules to determine liability for a tort that governs one aspect of the duty to compete fairly. This is particularly true where, as in the legal profession, two developments have taken place: (1) the ethical standards governing competition have become more permissive; and (2) actual competition for clients has increased. To carry out the pohicies underlying the loosening of restrictions on competition-to allow freer competition for clients, and to provide clients with greater opportunities to make a meaningful choice as to representation-the standards of a tort that regulates one aspect of that competition should, if possible, be made more clear. Therefore, given the regulated nature of the legal profession, and the recent move toward mcreased competition, a separate tort standard for the profession is appropriate. ${ }^{204}$

200. Goodman, 275 U.S. at 70.

201. Cf. Pound, Mechanical Jurisprudence, 8 Colum. L. REV. 605 (1908) (discussing the intuitive appeal of a "scientific law" that conforms to reason, uniformity, and certainty).

202. See supra notes $87-114$ and accompanying text.

203. Id.

204. The same considerations may suggest a similar approach to other regulated professions and areas of business. 
3. Using the Proposed Test as a Framework for Analysis Rather Than as a Separate Test

For those who object to adopting such a tailored standard as the one proposed here, I would offer the proposed test at least as an example of how courts should think about the interference tort in the departingattorney context. As this Comment has demonstrated, all departingattorney situations share a common factual pattern. By focusing on this pattern, soine of the factors identified by the Restatement can be pared away from the liability analysis; other factors can be eliminated from consideration coinpletely. As a consequence, the courts' inquiry will be more focused on the truly relevant factors, thereby allowing departing attorneys to inore accurately predict what they can and cannot do.

The proposed test need not be regarded as an exception to the general rule of liability. Rather, the test can be used to focus the courts' inquiry on the factors truly relevant to assessing whether a departing attorney's conduct was improper.

\section{IV}

\section{Applying the Proposed Test}

\section{A. Adler, Barish, Daniels, Levin \& Creskoff v. Epstein}

The Adler, Barish courts directly addressed the issues of whetlier the departing associates' conduct had violated the Permsylvania Code of Professional Responsibility, and whetler the Code's proscription could constitutionally be applied to the associates. ${ }^{205}$ While the appellate court held that the conduct did not violate the Code, it also noted that "[e]ven if [the associates'] conduct did aniount to solicitation ... [a] finding of 'solicitation' does not foreclose the possibility that the conduct is nonetheless privileged."206 In other words, the court suggested that certain conduct could be "solicitation" and prohibited by the Code, yet at the same time not be "improper" for purposes of determining liability for interference with contractual relations.

The Pennsylvania Supreine Court, on the other liand, exphicitly found that the associates' conduct did violate the Code, and that the Constitution permitted regulation of that conduct. ${ }^{207}$ In evaluating whether the associates' conduct was "innproper," the court found that the associates' departure from recognized ethical codes was significant in

205. $252 \mathrm{~Pa}$. Super. 553, 382 A.2d 1226 (1977). The constitutional issue was raised because the law firm sought injunctive relief. See supra text accompanying notes 118-33.

206. Id. at 562, $382 \mathrm{~A} .2 \mathrm{~d}$ at 1231 . The court argued that such a finding would not be dispositive since "the imstant proceeding is not a disciplinary one." Id. Perhaps because the court did not find the conduct to be "solicitation," it did not feel compelled to address the issue of what weight such a finding would have on the private action.

207. 482 Pa. 416, 393 A.2d 1175 (1978), cert. denied, 442 U.S. 907 (1979). 
evaluating the associates' conduct. ${ }^{208}$ Indeed, while invoking the full array of Restatement factors for determining whether an interference is improper, the court ultimately focused almost exclusively upon the nature of the associates' conduct, and the effects such conduct might have upon the chents and the law firm. ${ }^{209}$

If the associates' conduct did violate the Pennsylvania ethical code, the proposed test would reach the same result as that of the Pennsylvania Supreme Court. Analyzing the facts of the case under the proposed test, however, would explicitly recognize that liability should be determined by the nature of the associates' conduct: if violative of the Pennsylvania Code of Professional Responsibility, the interference would be "improper." 210 Thus, the approach of the test would be to focus exclusively upon the relationship between the associates' conduct and the Pennsylvania ethical rules, with particular attention to whether the purposes behind the rules, the state interests in preventing false and misleading statements and situations presenting danger of undue influence, are present.

Under the proposed test, the inquiry in this case would proceed as follows. First, did the departing associates make any false or misleading statements? As noted before, this would include material misrepresentations, statements that cannot be factually verified (such as quality comparisons), and statements hikely to cause nnjustified expectations (such as the promise of a favorable outcome). The defendants in Adler, Barish did not make any such statements and thus would pass the first hurdle. Second, did the departing associates have prior professional relationships with the clients? If so, the prohibition against solicitation would not apply, and they could offer services to the clients. If no prior relationship existed, they could not do so. It is not clear from the court's recitation of the facts whether the defendants had any prior relationships with the clients in question. Therefore, it is unclear whether their efforts to lure the clients away from the firm ran afoul of the prohibition against solicitation. If there was no prior relationship, the defendants would be subject to tort liability under the proposed test.

\section{B. Rosenfeld, Meyer \& Susman v. Cohen}

Analysis of Rosenfeld ${ }^{211}$ under the proposed test requires distinguishing between acts by the ex-partners which violate their fiduciary

208. Id. at 434, 393 A.2d at 1184 (quoting RESTATEMENT (SECOND) OF TORTS $\S 767$ comment c (1979)).

209. Id. at $434-37,393 \mathrm{~A} .2 \mathrm{~d}$ at $1184-86$.

210. The proposed approach therefore rejects the dictum of the intermediate appellate court to the effect that a finding of a violation of ethical rules does not resolve the inquiry of impropriety.

211. 146 Cal. App. 3d 200, 194 Cal. Rptr. 180 (1983). See supra text accompanying notes 13450. 
duties as partners (and are best resolved under prevailing partnership law) and acts by the ex-partners which may have ainounted to "improper" interference. The behavior of the ex-partners which allegedly caused the interference included statements made to the chent to the effect that the firm could not adequately represent the client, and that only the ex-partners could effectively represent the chent. This allegation raises two potential sources of liability under the proposed test.

First, the statements regarding the law firm's ability, if shown to be defainatory, would subject the ex-partners to liability under the first part of the test as independently unlawful behavior. Interfering with the firm's contract with the client in this manner is improper and should not be permitted. ${ }^{212}$

Another potential ground upon which the firm in Rosenfeld would be able to loold the ex-partners hable under the proposed test is if their conduct violated ethical rules. Under the Model Rules, the ex-partners may lave violated the rule against false or misleading stateinents im two respects. First, representations as to the quality of their services versus those of the firm would be misleading because they are factually unverifiable. Second, if the ex-partners promised the chent a favorable outcoine in the case, this would be misleading because it would create an unjustified expectation of success in the client.

In suin, analysis of Rosenfeld under the proposed test would scrutinize the conduct of the ex-partners in light of the standards of tort law and ethical rules. Liability would arise froin a violation of one of these bodies of law. Other issues concerning the ex-partners' violation of fiduciary duties owed as ex-partners wonld not be considered in connection with the determination of interference tort liability. On the facts as recited by the appellate court, the ex-partners inay have slandered the firm by disparaging its ability to handle the case, and they may have violated ethical rules by inaking misleading representations as to their coinparative abilities. If they violated either tort law or ethical rules, the proposed test would hold thein liable for intentional interference.

\section{Interference With Prospective Relations}

While Adler, Barish and Rosenfeld involved situations in which the firms had existing contingent fee contracts with the clients, the proposed test would also cover clains by a firm against departing attorneys for interference with prospective relations with firm clients. For exainple, while there is no existing "contract" in the case where the firm represents

212. Of course, the firm might also have a cause of action against the ex-partners for defamation. However, where the interfering party induces breach by making fraudulent representations to the client, the interference tort provides the party interfered with (here, the firm) with its only recourse against the interfering party. 
the client on an hourly basis, the firm does inaintain an econonic relationship with the chent. Departing attorneys nnay seek to establish ongoing business relations with those clients. Under prevailing interference tort doctrine, the firm, under these circuinstances, is entitled to protection from "improper" interference.

Under the proposed test, the departing attorney would liave a clear standard against which she could tailor her communications with the client. The departing attorney would have to be sure not to violate tort or criminal law in her actions, and to keep leer communications witl the potential client within the ethical rules by not making "false or inisleading" stateinents as defined by the Model Rules. So long as she stayed within these limits, there would be no fear of liability for interference with the firm's relationship with the client.

Breach of fiduciary duties to the foriner firm would not be relevant to interference tort liability. The departing attorney also need not worry about whether the client rehes primarily on the firm or the individual attorney for representation. As long as the attorney does not act unlawfully or in a way violative of the ethical rules, the attorney has as inucl right to seek future representation of the client as does the firm.

\section{CONCLUSION}

The "interference" torts protect parties in their economic relations froin interference by third parties where the interference is "inproper." The Restatement provides a list of seven factors to be considered in deter1mining whether an interference is "improper," but gives hittle guidance as to low the factors should be considered together. Because the factual patterns in the departing-attorney context are sufficiently crystallized to perimit a inore developed test, this Comment argues that the courts should focus on the beliavior of the departing attorney and avoid consideration of irrelevant and inappropriate factors. This Coininent proposes two bases of liability.

The first source of liability arises where the attorney's behavior is independently wrongful. If the attorney's behavior, under prevailing state law, is either independently tortious or crininal, the attorney sliould be lield liable to the firm for improper interference with relations between the firm and the client.

The second source of liability arises where tle attorney's conduct violates state ethical rules regulating the conduct of attorneys. Sucli a violation would similarly subject the attorney to liability for inproper interference.

This Comment apphed the proposed analysis to two reported cases which have raised the issue of improper interference in the departingattorney context, as well as to the prospective relations situation. The 
examples demonstrate that the proposed test carries out the goals of the tort while remaining sufficiently flexible to take account of factual permutations. This approach also avoids the consideration of factors relevant to different duties of the departing attorney, as well as of questions which are not resolvable.

Acceptance of the proposed test would probably make it more difficult for law flrms to hold ex-partners and ex-associates liable for interference with economic relations between the firm and a former client, since the proposed test narrows the permissible bases of liability. This result is consistent with the recent movement of the legal profession toward a more competitive market, ${ }^{213}$ without preventing the interference tort from proscribing the types of unfair competition with which it has traditionally been concerned.

Mark D. Flanagan*

213. See supra text accompanying notes $2-5$.

* B.A. 1984, University of California, Los Angeles; J.D. 1987, Boalt Hall School of Law, University of California, Berkeley. 


\section{,}

